\title{
EFFECTS OF GINSENOSIDE Rg3 ON THE PROLIFERATION OF GLIOMA CELLS AND NF-אB SIGNALLING PATHWAY
}

\author{
YINDONG MU ${ }^{1}$, YANG LIU ${ }^{2}$, YANKUN HAO $^{3}$, LEI YAN $^{1}$, JUN LIANG $^{4}$, JIANJIANG DONG $^{1}{ }^{*}$ \\ ${ }^{1}$ Department of Histology and Embryology, Mudanjiang Medical University, Mudanjiang 157011, China \\ ${ }^{2}$ Office of Educational Administration, Mudanjiang Medical University, Mudanjiang 157011, China \\ ${ }^{3}$ Department of Medical Function, Mudanjiang Medical University, Mudanjiang 157011, China \\ ${ }^{4}$ Stem Cell Institute, Mudanjiang Medical University, Mudanjiang 157011, China
}

*corresponding author: dongjianjiangmdjmu@163.com

Manuscript received: December 2018

\begin{abstract}
The objective of this study was to assess the effects of Ginsenoside $\operatorname{Rg} 3$ on the proliferation of glioma cells and NF- $\mathrm{NB}$ (nuclear factor kappa-light-chain-enhancer of activated B cells) signalling pathway and to provide a reliable reference for clinical treatments. The glioma U251 cells were cultured and treated with Ginsenoside Rg3 at different concentrations $(0,20$, 40,80 , and $160 \mu \mathrm{g} / \mathrm{mL}$ ) for 24,48 , and $72 \mathrm{~h}$, respectively. The morphological changes of U251 cells were observed before and after treatment with Ginsenoside Rg3. Cell proliferation was detected by the MTT assay. The expression of P65 gene promoter was detected by Dual-Luciferase Reporter Assay. Besides, the expressions of p65 and inhibitory kappa B (IкB) were detected by Western blotting. U251 cells before Ginsenoside Rg3 treatment were structurally intact and after the treatment started to present cell shrinkage and cellular debris that become more pronounced with the increase of the treatment duration. The lower concentration of Ginsenoside Rg3 could promote the expression of the P65 gene promoter, while the expression gradually decreased with the increase of Ginsenoside $\mathrm{Rg} 3$ concentration. The expression of IкB $\alpha$ protein gradually increased with the increase of Ginsenoside $\operatorname{Rg} 3$ concentration. In conclusion, Ginsenoside $\operatorname{Rg} 3$ can effectively

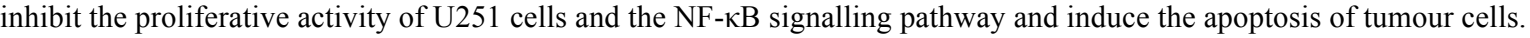

\section{Rezumat}

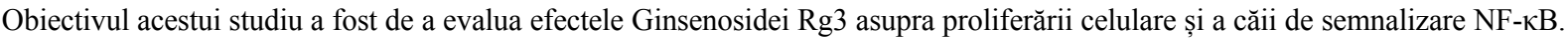
Celulele de gliom U251 au fost cultivate și tratate cu Ginsenosid Rg3 la diferite concentrații (0, 20, 40, 80 și $160 \mu \mathrm{g} / \mathrm{mL})$ timp de 24, 48 și, respectiv, 72 h. Modificările morfologice ale celulelor U251 au fost observate înainte și după tratamentul cu Ginsenosid Rg3. Proliferarea celulară a fost evaluată prin testul MTT. Expresia promotorului genei P65 a fost determinată prin testul Dual-Luciferase Reporter. În plus, expresiile p65 și inhibitorul kappa B (IкB) au fost determinate prin analiză Western Blot. Tratamentul celulelor U251 cu Ginsenosid Rg3 a determinat contracția celulară şi apariţia unor debriuri celulare dependente de durata expunerii. Concentrația mică de Ginsenosid Rg3 ar putea determina expresia promotorului genei P65, în timp ce creșterea concentrației de Ginsenosid Rg3 va declanșa scăderea graduală a acesteia. Expresia proteinei I $\mathrm{B} \alpha$ crește treptat odată cu creșterea concentrației de Ginsenosid Rg3. În concluzie, Ginsenosid Rg3 poate inhiba eficient

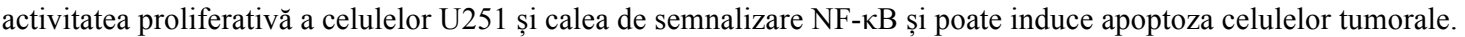

Keywords: Ginsenoside Rg3, glioma, cell proliferation, NF- $\mathrm{BB}$ signalling pathway

\section{Introduction}

Glioma is a common central nervous system tumour, associated with rapid growth, invasiveness and poor prognosis [1]. Although there are a variety of therapeutic approaches, glioma patients have a shorter survival after diagnosis $[2,3]$. Several chemotherapeutic strategies have been assessed in order to remove the residual tumour cells with different success rates [4-6].

Ginsenoside $\operatorname{Rg} 3$ is a panaxadiol that is found in white and red Panax ginseng, Araliaceae family [7]. Ginsenoside Rg3 has multiple pharmacological effects, such as anti-tumour [8], anti-inflammation [9], antioxidant $[10,11]$. As one of the most important nuclear transcription factors in cells, NF- $\mathrm{kB}$ (nuclear factor kappa-light-chain-enhancer of activated $\mathrm{B}$ cells) is

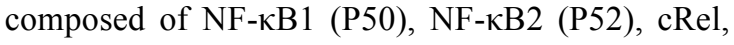
RelA (P65), and RelB (8). Generally, the main form of $\mathrm{NF}-\kappa \mathrm{B}$ is a heterodimer composed of P50 and P65 subunits, in which P65 is the main active part [13]. Inhibitory kappa $\mathrm{B}(\mathrm{I} \kappa \mathrm{B})$ is an inhibitor- $\kappa$ binding protein of $N F-\kappa B$, that is composed of $I \kappa B \alpha, I \kappa B \beta$, $\mathrm{I} \kappa \mathrm{B} \gamma, \mathrm{I} \kappa \mathrm{B} \varepsilon, \mathrm{p} 100, \mathrm{p} 105, \mathrm{Bcl}-3$, and I $\mathrm{B}-\mathrm{R}$ [14]. The $\mathrm{NF}-\kappa \mathrm{B}$ pathway mediates a variety of target genes, including cell proliferation and apoptosis genes, as well as cell adhesion factors $[15,16]$ and mediates abnormal expressions of tumour-associated genes, promotes cell proliferation, and induces the development of cancer $[17,18]$. NF- $\kappa \mathrm{B}$ is specifically activated in glioma cells and the activation level increases with the progression of the tumour [19]. So, the inhibition of NF- $\mathrm{KB}$ activity would promote the apoptosis of 
tumour cells and targeting NF- $\kappa \mathrm{B}$ could be a good antitumoral strategy. This study aimed to investigate the effect of different concentrations of Ginsenoside $\mathrm{Rg} 3$ on the proliferation of glioma U251 cells and the effects on the NF- $\kappa \mathrm{B}$ signalling pathway.

\section{Materials and Methods}

Culture, passage, and counting of glioma U251 cells U251 glioma cells were purchase from Nanjing Cobioer (Nanjing Cobioer, China). The U251 glioma cells in logarithmic growth phase were grown as monolayer cultures in the culture medium (Hyclone Corporation, USA) under $5 \% \mathrm{CO}_{2}$ atmosphere and $37^{\circ} \mathrm{C}$. The cells were digested with trypsin (Gibco Corporation, USA) and were observed each day for the morphology and growth using an optic microscope (Olympus, Japan). The culture medium of cells was renewed every 2 days. The morphology and growth of the cells were observed under a microscope (Olympus Corporation, Japan). The count of the cell was done after Trypan blue (Kirgen Corporation, USA) addition and observed under a microscope (Olympus, Japan).

Microscopic observation of the morphological changes of U251 cells after Ginsenoside Rg3 treatment U251 cells grown in appropriate conditions were divided into five groups. The cells were inoculated into a 6-well plate and exposed to the DMEM/F12 medium (Hyclone Corporation, USA) that contained Ginsenoside Rg3 in concentrations of $0,20,40,80$, and $160 \mu \mathrm{g} / \mathrm{mL}$ (provided by Dalian Tianfu Institute of Medicine, China). The morphological changes of U251 cells were observed after 24, 48, and $72 \mathrm{~h}$ of culture under a microscope (Shanghai Caikon Optical Instrument, China).

Detection of the proliferation activity of U251 cells by MTT assay

U251 cells $\left[5 \times 10^{3}\right.$ cells/well] were inoculated into a 6-well plate and cultured in an incubator at $37^{\circ} \mathrm{C}$ in $5 \% \mathrm{CO}_{2}$ atmosphere. The cells were divided in 5 experimental groups, and each group has 3 subgroups. The experimental groups were: Control group treated with culture media containing dimethyl sulfoxide (DMSO) instead of Ginsenoside Rg3; Experimental groups treated with culture media containing Ginsenoside Rg3 in different concentrations: 20, 40, 80, and 160 $\mu \mathrm{g} / \mathrm{mL})$. The Ginsenoside $\mathrm{Rg} 3$ is soluble in dimethyl sulfoxide (DMSO), so the control group was treated only with the solvent (DMSO).

Each subgroup was exposed to the treatment for 24, 48 , and respectively $72 \mathrm{~h}$. The MTT assay was used to detect the optical density (OD) value of cells at the wavelength of $570 \mathrm{~nm}$. Each test was performed in triplicate and the cell viability was calculated using the following formula:

Cell viability (MTT assay) $(\%)=[($ experimental group blank group)/(control group - blank group) $] \times 100 \%$.
Cell scratch assay

The well-growing U251 cells inoculated in a 6-well plate were taken out from the incubator. After draining the culture solution, a ruler was applied to draw a horizontal line with a marker on the back of the 6well plate; meanwhile, a sterile pipette tip $(10 \mu \mathrm{L})$ was used for aligning with the scale; the horizontal line drawn on the back of the 6-well plate was drawn as evenly as possible. The cells were exposed to different concentrations of Ginsenoside $\operatorname{Rg} 3(0,20$, 40,80 , and $160 \mu \mathrm{g} / \mathrm{mL}$ ), and each group was divided in 3 sub-groups that correspond to the 3 periods of treatment: 24,48 , and respectively, $72 \mathrm{~h}$. The 6-well plate was observed using an inverted fluorescence microscope (Olympus, Japan) and the migration distance of the cells was measured and recorded. Cell migration was calculated using the following formula:

Cell migration $(\%)=($ cell distance on both sides at the time of scratch - cell distance on both sides at the time of detection)/cell distance on both sides at the time of scratch $\times 100 \%$.

Detection of P65 gene promoter expression in cells by Dual-Luciferase Reporter Gene Assay

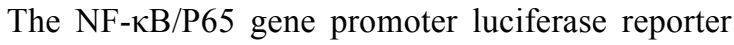
adenovirus recombinant plasmid (AdP65-Fluc), the luciferase reporter adenovirus empty plasmid (AdFluc), and the Renilla luciferase adenovirus internal reference plasmid (Ad-Rluc) were obtained from Wuhan Merck Biotechnology Co Ltd (Wuhan, China). The virus transfection was divided into three groups: the experimental group (AdP65-Fluc and Ad-Rluc cotransfected into $\mathrm{U} 251$ cells $[\mathrm{MOI}=5])$, the control group (Ad-Fluc and Ad-Rluc co-transfected into U251 cells), and the blank group (no virus transfected into U251 cells). U251 cells in logarithmic growth phase were taken out from the incubator, counted after tryptic digestion, and inoculated into a 24-well plate at a density of $1 \times 10^{5}$ cells/well. After $24 \mathrm{~h}$ of culture, the original medium was aspirated, and the wells were washed with PBS (Shanghai Fushen Biotechnology, China). Then, the corresponding adenovirus recombinant plasmid (AdP65-Fluc, Ad-Fluc, and Ad-Rluc) was added into the culture medium of each well in accordance with the experimental group; the culture medium in each well was well mixed, and the plate was cultured in an incubator at $37^{\circ} \mathrm{C}$. The cultures were observed daily using a fluorescence microscope (Olympus, Japan) to observe the expression of green fluorescent protein (GFP).

The transfected U251 cells were inoculated into a 6 -well plate at a density of $5 \times 10^{5}$ cells/well. Based on the experimental group, $2 \mathrm{~mL}$ of Ginsenoside $\mathrm{Rg} 3$ with different concentrations $(0,20,40,80$, and $160 \mu \mathrm{g} / \mathrm{mL}$ ) was added into each well and each group was divided in 3 sub-groups, one for each period of drug treatment, 24, 48 and respectively 72 h. After 
FARMACIA, 2019, Vol. 67, 5

24,48 and respectively $72 \mathrm{~h}$ of treatment, the culture medium was aspirated, and the wells were rinsed once with PBS. Then, $500 \mu \mathrm{L}(1 \times)$ passive lysis buffer (PLB) (Shanghai Fushen Biotechnology, China) was added into each well; the plate was gently shaken for $15 \mathrm{~min}$ at room temperature. Next, the lysate was transferred to a 6-well white plate with 3 sub-holes in each group and stored in an icebox to be tested (The testing used 1 - $2 \mathrm{~s}$ delay and 5 - $10 \mathrm{~s}$ indication). Detection of P65 and IKB $\alpha$ expression in cells by Western blotting

U251 cells in logarithmic growth phase were counted after $0.25 \%$ trypsin digestion. Next, the U251 cells were inoculated into a 6 -well plate at a density of $2 \times$ $10^{5}$ cells/well. Based on the experimental group, each well was treated with $2 \mathrm{~mL}$ of culture medium with different concentrations of Ginsenoside $\mathrm{Rg} 3$ $(0,20,40,80$, and $160 \mu \mathrm{g} / \mathrm{mL})$ and each well was divided in 3 sub-holes, one for each period of drug treatment, 24 and 48 hours respectively. After incubation the cytoplasmic proteins and nuclear proteins of each group of cells were extracted and detected using the PMSF protease inhibitor (Beyotime Biotechnology, China). The extracted cytoplasmic protein and nuclear protein were separated by sodium dodecyl sulphatepolyacrylamide gel electrophoresis (SDS-PAGE), transferred and blocked. Then, the PVDF membrane was incubated with the primary antibody (Mouse antihuman P65 antibody, mouse anti-human Histon H3 antibody, mouse anti-human IKBa antibody, mouse anti-human $\beta$-actin antibody, Cell Signal Corporation, USA) (diluted with 5\% skim milk powder at 1000:1) overnight at $4{ }^{\circ} \mathrm{C}$. After the incubation PVDF membrane was washed and incubated with the secondary antibody (Horseradish peroxidase marked anti-mouse
IgG, Zhongshan Golden Bridge Biotechnology, China) (diluted with 5\% skim milk powder at 5000:1) for $1 \mathrm{~h}$ on a shaker at room temperature. After incubation, the PVDF membrane was washed with tris-buffered saline (TBS) + Tween 20 (TBST) solution for $10 \mathrm{~min}$ 3 consecutive times. Next, the PVDF membrane treated with the enhanced chemiluminescence reagent (Beyotime Biotechnology, China) for $1 \mathrm{~min}$, X-ray films were proceeded, scanned and photographed by a gel imaging system (BIO-RAD Corporation, China). Statistical analysis

Data were analysed by SPSS 19.0 software (IBM, Armonk, NY, USA). The measured data were expressed as mean \pm standard deviation. Experimental results were analysed by one-way analysis of variance (ANOVA). The comparisons among the groups were made by independent-samples t-test. A value of $\mathrm{p}<0.05$ was considered statistically significant.

\section{Results and Discussion} Effects of Ginsenoside Rg3 on morphological changes
of U251 cells

The U251 cells without Ginsenoside Rg3 were in normal growth condition with an intact cell structure (Figure 1A). In the ginsenoside $\mathrm{Rg} 3$ treated U251 cells, it was observed a dose-dependent effect on the behaviour of the cells. By increasing the concentration of the treatment, the cells began to shrink, and the adherent cells were in relatively small quantities, with massive amount of suspended cell debris around. By increasing the duration of exposure to Ginsenoside $\mathrm{Rg} 3$, the cell shrinkage was more obvious, the cell density significantly decreased, and the cellular debris increased.
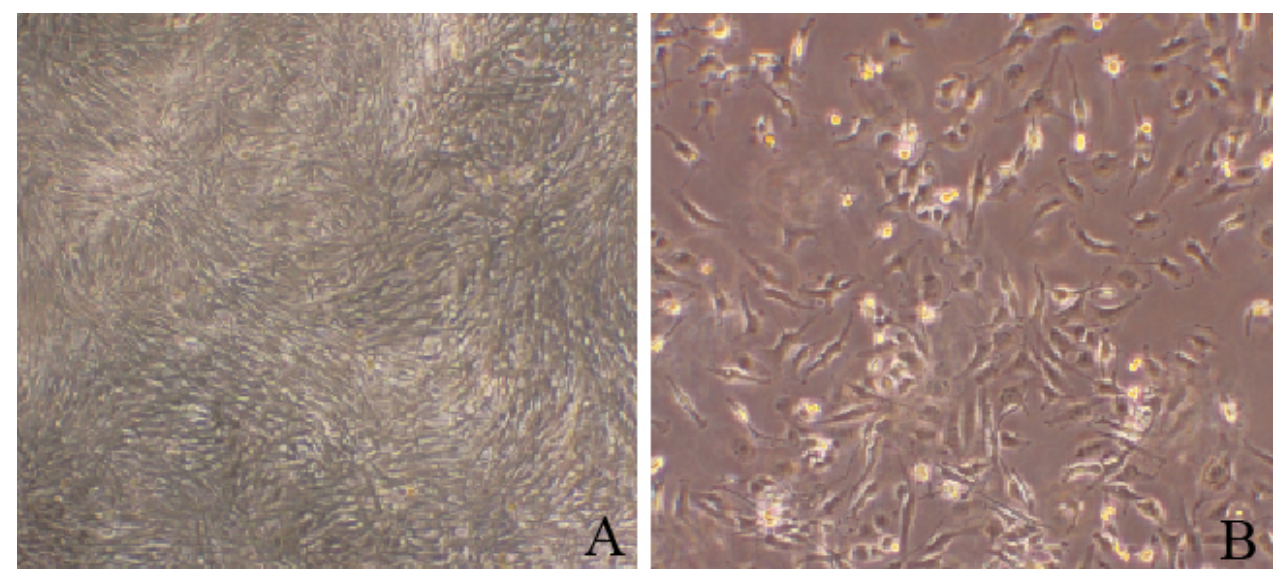

Figure 1.

Effects of Ginsenoside Rg3 on morphological changes of U251 cells (A: U251 cells in normal culture; B: U251 cells treated with $80 \mu \mathrm{g} / \mathrm{mL}$ Ginsenoside Rg3 for $24 \mathrm{~h})(\times 100)$

Effects of Ginsenoside $\mathrm{Rg} 3$ on proliferative properties of U251 cells

As shown in Table I, at the same period of treatment, the viability of U251 cells decreased with the increase in Ginsenoside $\operatorname{Rg} 3$ concentration. At the same concentration of Ginsenoside $\mathrm{Rg} 3$, the viability of U251 cells decreased as the period of exposure increased. 
Effects of Ginsenoside $\mathrm{Rg} 3$ on the viability of U251 cells

\begin{tabular}{cccccc}
\hline Duration $(\mathrm{h})$ & $0 \mu \mathrm{g} / \mathrm{mL}$ & $20 \mu \mathrm{g} / \mathrm{mL}$ & $40 \mu \mathrm{g} / \mathrm{mL}$ & $80 \mu \mathrm{g} / \mathrm{mL}$ & $160 \mu \mathrm{g} / \mathrm{mL}$ \\
\hline 24 & $100.00 \pm 0.81$ & $88.37 \pm 1.76^{\mathrm{a}}$ & $75.11 \pm 2.18^{\mathrm{ab}}$ & $67.27 \pm 3.16^{\mathrm{abc}}$ & $51.92 \pm 2.17^{\mathrm{abc}}$ \\
48 & $99.96 \pm 0.98$ & $75.93 \pm 1.67^{\mathrm{a} *}$ & $62.18 \pm 2.93^{\mathrm{ab} *}$ & $54.26 \pm 3.28^{\mathrm{abc} *}$ & $43.18 \pm 2.28^{\mathrm{abc} *}$ \\
72 & $99.41 \pm 0.88$ & $78.27 \pm 1.92^{\mathrm{a} *}$ & $59.38 \pm 1.64^{\mathrm{ab} *}$ & $52.29 \pm 2.02^{\mathrm{abc} *}$ & $41.22 \pm 1.27^{\mathrm{abc} *}$ \\
\hline
\end{tabular}

Compared with the $0 \mu \mathrm{g} / \mathrm{mL}$ group, ${ }^{\mathrm{a}} \mathrm{p}<0.05$; compared with the $20 \mu \mathrm{g} / \mathrm{mL}$ group, ${ }^{\mathrm{b}} \mathrm{p}<0.05$; compared with the $40 \mu \mathrm{g} / \mathrm{mL}$ group, ${ }^{\mathrm{c}} \mathrm{p}<0.05$; compared with the $80 \mu \mathrm{g} / \mathrm{mL}$ group, ${ }^{\mathrm{d}} \mathrm{p}<0.05$; compared with the $24 \mathrm{~h}$ group, ${ }^{*} \mathrm{p}<0.05$

Effects of Ginsenoside Rg3 on migrating properties of U251 cells

As illustrated in Figure 2 and Table II, the Ginsenoside Rg3 could effectively inhibit the migrating abilities of U251 cells. At the same period of Ginsenoside
$\operatorname{Rg} 3$ treatment, the migrating abilities of U251 cells decreased with the increase of Ginsenoside Rg3 concentrations. At the same concentration of Ginsenoside $\mathrm{Rg} 3$, the migrating abilities of U51 cells decreased as the duration of the treatment increased.
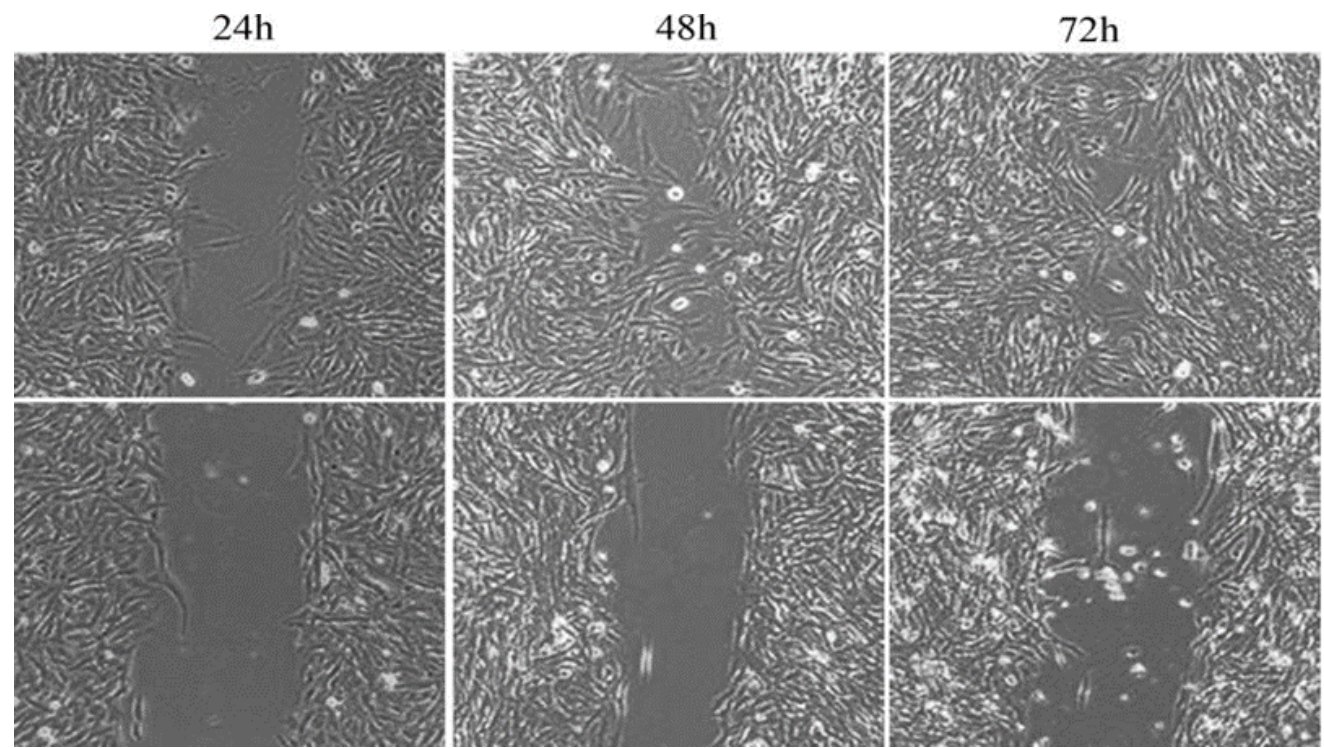

Oug $/ \mathrm{mL}$

Figure 2.

Effects of Ginsenoside Rg3 on the migration abilities of U251 cells $(\times 100)$

Table II

Ginsenoside Rg3 influences the migration abilities of U251 cells (\%)

\begin{tabular}{cccccc}
\hline Duration $(\mathrm{h})$ & $0 \mu \mathrm{g} / \mathrm{mL}$ & $20 \mu \mathrm{g} / \mathrm{mL}$ & $40 \mu \mathrm{g} / \mathrm{mL}$ & $80 \mu \mathrm{g} / \mathrm{mL}$ & $160 \mu \mathrm{g} / \mathrm{mL}$ \\
\hline 24 & $54.12 \pm 2.84$ & $47.18 \pm 5.21^{\mathrm{a}}$ & $41.19 \pm 6.15^{\mathrm{ab}}$ & $35.73 \pm 3.19^{\mathrm{abc}}$ & $27.73 \pm 3.19^{\mathrm{abcd}}$ \\
48 & $72.53 \pm 7.34$ & $62.18 \pm 8.02^{\mathrm{a} *}$ & $51.38 \pm 5.18^{\mathrm{ab} *}$ & $41.83 \pm 6.38^{\mathrm{abc} *}$ & $32.83 \pm 6.38^{\mathrm{abcd} *}$ \\
72 & $96.53 \pm 9.34$ & $82.27 \pm 9.28^{\mathrm{a} *}$ & $70.92 \pm 6.28^{\mathrm{ab} *}$ & $60.11 \pm 7.92^{\mathrm{abc} *}$ & $50.11 \pm 7.92^{\mathrm{abcd} *}$ \\
\hline
\end{tabular}

Compared with the $0 \mu \mathrm{g} / \mathrm{mL}$ group, ${ }^{a} \mathrm{p}<0.05$; compared with the $20 \mu \mathrm{g} / \mathrm{mL}$ group, ${ }^{b} \mathrm{p}<0.05$; compared with the $40 \mu \mathrm{g} / \mathrm{mL}$ group, ${ }^{{ }^{c} \mathrm{p}<0.05}$; compared with the $80 \mu \mathrm{g} / \mathrm{mL}$ group, ${ }^{\mathrm{d}} \mathrm{p}<0.05$; compared with the $24 \mathrm{~h}$ group, ${ }^{*} \mathrm{p}<0.05$
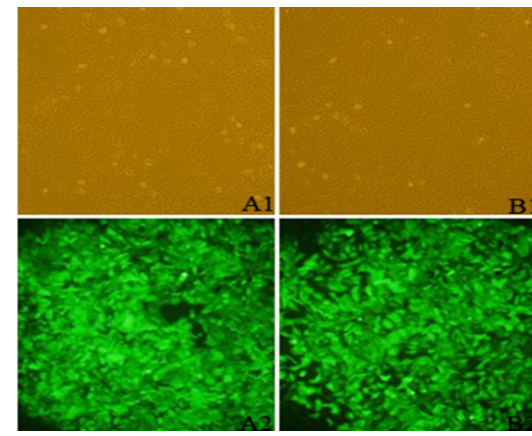

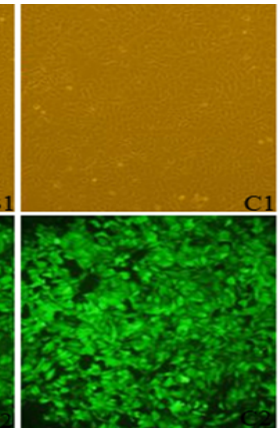

Figure 3.

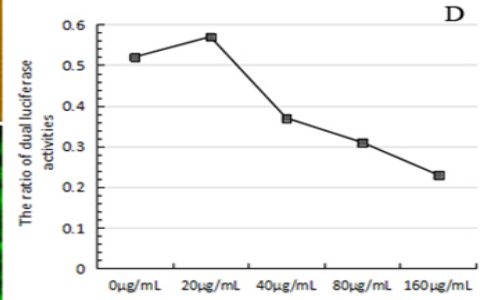

Adenovirus recombinant plasmid was transfected into U251 cells (48 h)

(A: AdP65-Fluc; B: Ad-Fluc; C: Ad-Rluc; D: effects of Ginsenoside Rg3 on P65 gene promoter of U251 cells; 1: ordinary optical microscope; 2 : fluorescence microscope $(\times 200)$ 
Effects of Ginsenoside Rg3 on P65 gene promoter of $U 251$ cells

The lower concentration of Ginsenoside Rg3 could promote the expression of P65 gene promoter (Figure 3). With the increase of drug concentrations, the expression of P65 gene promoter gradually decreasing compare with the control $(0 \mu \mathrm{g} / \mathrm{mL})$ group $(\mathrm{p}<0.05)$.
Effects of Ginsenoside Rg3 on the expressions of P65 and IKB $\alpha$ proteins in U25I cells

The results showed that as the concentration of Ginsenoside Rg3 increased, the expression of P65 protein in the nucleus gradually increased, while the expression of IKB $\alpha$ protein in cytoplasm gradually decreased after $48 \mathrm{~h}$ of exposure (Table III).

Table III

Effects of Ginsenoside $\mathrm{Rg} 3$ on the expressions of $\mathrm{P} 65$ and IKB $\alpha$ proteins in U251 cells

\begin{tabular}{cccccc}
\hline Concentration & $0 \mu \mathrm{g} / \mathrm{mL}$ & $20 \mu \mathrm{g} / \mathrm{mL}$ & $40 \mu \mathrm{g} / \mathrm{mL}$ & $80 \mu \mathrm{g} / \mathrm{mL}$ & $160 \mu \mathrm{g} / \mathrm{mL}$ \\
\hline $\mathrm{P} 65$ & $1.423 \pm 0.036$ & $1.386 \pm 0.017$ & $0.981 \pm 0.061$ & $0.582 \pm 0.013$ & $0.418 \pm 0.013$ \\
$\mathrm{IKB} \alpha$ & $0.189 \pm 0.014$ & $0.329 \pm 0.011$ & $0.608 \pm 0.016$ & $0.716 \pm 0.017$ & $0.822 \pm 0.016$ \\
\hline
\end{tabular}

The concentration of each group was compared with the $0 \mu \mathrm{g} / \mathrm{mL}$ group, $\mathrm{p}<0.05$

A previous study showed that Ginsenoside $\mathrm{Rg} 3$ could reduce the expressions of lipopolysaccharide (LPS)-induced inflammatory factors [20]. Besides that, Ginsenoside Rg3 could inhibit the proliferation of tumour cells [21, 22]. In this study, it was showed that Ginsenoside Rg3 has a significant inhibitory effect on the proliferation of U251 cells, and its effect is dose depending.

Zhen et al. [23] showed that the NF- $\mathrm{KB}$ signalling pathway has a certain correlation with the degree of malignancy, invasion, and apoptosis of glioma. Other studies suggested that Ginsenoside Rg3 could inhibit the release of TNF- $\alpha$ [24] and block the NF- $\kappa \mathrm{B}$ signalling pathway [25]. Our study showed that a low concentration of Ginsenoside $\mathrm{Rg} 3$ induced the expression of the P65 gene promoter in the NF- $\kappa \mathrm{B}$ signalling pathway; however, the expression of the P65 gene promoter decreased with the increase of Ginsenoside Rg3 concentrations. The Western blotting results demonstrated that the expression of IKB $\alpha$ protein increased with the increase of Ginsenoside $\mathrm{Rg} 3$ concentrations, while the expression of P65 gene promoter showed a decreasing trend. Since IKB $\alpha$ protein could inhibit the activation of P65 gene promoter, its entry into the nucleus was reduced $[26$, 27]. It can be concluded that the decreased expression of P65 gene promoter is caused by the inhibitory effect of Ginsenoside Rg3 on P65 gene promoter; however, it cannot exclude the possibility of IKB $\alpha$ to inhibit the entry of P65 gene promoter into the nucleus.

\section{Conclusions}

Ginsenoside $\mathrm{Rg} 3$ can effectively inhibit the proliferation of U251 cells. Moreover, in the NF- $\mathrm{BB}$ signalling pathway, Ginsenoside $\operatorname{Rg} 3$ may induce the expression of $\mathrm{IKB} \alpha$ protein in the cytoplasm and inhibit its degradation and the expression of the P65 gene promoter, thereby reducing the expression of P65 gene promoter and the entry of activated P65 gene promoter into the nucleus. Consequently, Ginsenoside
Rg3 inhibits the NF- $\mathrm{kB}$ signalling pathway and induces the apoptosis of tumour cells.

\section{Acknowledgement}

This work was supported by the Mudanjiang Science and Technology Planning Project (Z2018s043).

\section{Conflicts of interest}

The authors declared that they have no conflicts of interest in this work.

\section{References}

1. Zhong JT, Xu Y, Yi HW, Su J, Yu HM, Xiang XY, Li XN, Zhang ZC, Sun LK, The BH3 mimetic S1 induces autophagy through ER stress and disruption of Bcl-2/Beclin 1 interaction in human glioma U251 cells. Cancer Lett., 2012; 323(2): 180-187.

2. Gandía-González ML, Cerdán S, Barrios L, LópezLarrubia P, Feijoó PG, Palpan AJr, Roda JM, Solivera J, Assessment of overall survival in glioma patients as predicted by metabolomic criteria. Front Oncol., 2019; 9: 1-11.

3. Ginghină O, Negrei C, Hudiță A, Ioana-Lavric V, Gălățeanu B, Dragomir S, Burcea Dragomiroiu GTA, Bârcă M, Nițipir C, Diaconu CC, Pantea Stoian AM, Iordache N, Bălănescu A, In vitro impact of some natural compounds on HT-29 colorectal adenocarcinoma cells. Farmacia, 2017; 65(6): 947-953.

4. Wang N, Zhang Q, Luo L, Ning B, Fang Y, $\beta$-asarone inhibited cell growth and promoted autophagy via P53/Bcl-2/Bclin-1 and P53/AMPK/mTOR pathways in Human Glioma U251 cells. J Cell Physiol., 2018; 233(3): 2434-2443.

5. Taghizadehghalehjoughi A, Hacimuftuoglu A, Cetin M, Ugur AB, Galateanu B, Mezhuev Y, Okkay U, Taspinar N, Taspinar M, Uyanik A, Gundogdu B, Mohammadzadeh M, Nalci KA, Stivaktakis $P$, Tsatsakis A, Jung TW, Jeong JH, Abd El-Aty AM, Effect of metformin/irinotecan-loaded poly-lacticco-glycolic acid nanoparticles on glioblastoma: in vitro and in vivo studies. Nanomed (London), 2018; 13(13): 1595-1606. 
FARMACIA, 2019, Vol. 67, 5

6. Gong HD, Li HZ, Li JK, Wang C, Myricetin inhibition on murine glioma GL261 cell line. Farmacia. 2017; 65(6): 934-939.

7. Liang Y, Zhao S, Progress in understanding of ginsenoside biosynthesis. Plant Biol (Stuttg), 2008; 10(4): 415-421.

8. Kim SM, Lee SY, Cho JS, Son SM, Choi SS, Yun YP, Yoo HS, Yoon DY, Oh KW, Han SB, Hong JT, Combination of ginsenoside Rg3 with docetaxel enhances the susceptibility of prostate cancer cells via inhibition of NF-kappaB. Eur J Pharmacol., 2010; 631(1-3): 1-9.

9. Kim BM, Kim DH, Park JH, Surh YJ, Na HK. Ginsenoside Rg3 inhibits constitutive activation of NF- $\kappa \mathrm{B}$ signaling in human breast cancer (MDAMB-231) cells: ERK and Akt as potential upstream targets. J Cancer Prev., 2014; 19(1): 23-30.

10. Sun M, Ye Y, Xiao L, Duan X, Zhang Y, Zhang H, Anticancer effects of ginsenoside $\operatorname{Rg} 3$ (Review). Int J Mol Med., 2017; 39(3): 507-518.

11. Razgonova MP, Veselov VV, Zakharenko AM, Golokhvast KS, Nosyrev AE, Cravotto G, Tsatsakis A, Spandidos DA, Panax ginseng components and the pathogenesis of Alzheimer's disease (Review). Mol Med Rep., 2019; 19(4): 2975-2998.

12. Nandhu MS, Kwiatkowska A, Bhaskaran V, Hayes $\mathrm{J}$, Hu B, Viapiano MS, Tumor-derived fibulin-3 activates pro-invasive NF- $\mathrm{KB}$ signaling in glioblastoma cells and their microenvironment. Oncogene, 2017; 36(34): 4875-4886.

13. Thomas NS, George K, Selvam AAA, Anticancer mechanism of troxerutin via targeting Nrf2 and NF$\kappa \mathrm{B}$ signalling pathways in hepatocarcinoma cell line. Toxicol In Vitro, 2019; 54: 317-329.

14. Jumnongprakhon $\mathrm{P}$, Govitrapong $\mathrm{P}$, Tocharus $\mathrm{C}$, Pinkaew D, Tocharus J, Melatonin protects methamphetamine-induced neuroinflammation through $\mathrm{NF}-\kappa \mathrm{B}$ and $\mathrm{Nrf} 2$ pathways in glioma cell line. Neurochem Res., 2015; 40(7): 1448-1456.

15. Vlachostergios PJ, Papandreou CN, The Bmi-1/NF$\kappa B / V E G F$ story: another hint for proteasome involvement in glioma angiogenesis?. $J$ Cell Commun Signal., 2013; 7(4): 235-237.

16. Hamza RZ, El-Shenawy NS, Anti-inflammatory and antioxidant role of resveratrol on nicotineinduced lung changes in male rats. Toxicol Rep., 2017; 4: 399-407.

17. Yue C, Niu M, Shan QQ, Zhou T, Tu Y, Xie P, Hua L, Yu R, Liu X, High expression of Bruton's tyrosine kinase (BTK) is required for EGFR-induced $\mathrm{NF}-\mathrm{\kappa B}$ activation and predicts poor prognosis in human glioma. J Exp Clin Cancer Res., 2017; 36(1): $1-11$.

18. Kadry MO, Abdel-Megeed RM, El-Meliegy E, Abdel-Hamid AHZ, Crosstalk between GSK-3, cFos, NF kappa B and TNF-alpha signaling pathways play an ambitious role in chitosan nanoparticles cancer therapy. Toxicol Rep., 2018; 5: 723-727.

19. Lee DW, Ramakrishnan D, Valenta J, Parney IF, Bayless KJ, Sitcheran R, The NF- $\kappa B$ RelB protein is an oncogenic driver of mesenchymal glioma. PLoS One, 2013; 8(2): 1-10.

20. Bae EA, Kim EJ, Park JS, Kim HS, Ryu JH, Kim DH. Ginsenosides Rg3 and Rh2 inhibit the activation of ap-1 and protein kinase a pathway in lipopolysaccharide/ interferon- $\gamma$-stimulated BV-2 microglial cells. Planta Med., 2006; 72(7): 627-633.

21. Park SM, Choi MS, Sohn NW, Shin JW, Ginsenoside Rg3 attenuates microglia activation following systemic lipopolysaccharide treatment in mice. Biol Pharm Bull., 2012; 35(9): 1546-1552.

22. Beurel E, Kornprobst M, Blivet-Van Eggelpoël MJ, Cadoret A, Capeau J, Desbois-Mouthon C, GSK3beta reactivation with LY294002 sensitizes hepatoma cells to chemotherapy-induced apoptosis. Int J Oncol., 2005; 27(1): 215-222.

23. Zhen ZG, Ren SH, Ji HM, Ma JH, Ding XM, Feng FQ, Chen SL, Zou P, Ren JR, Jia L, Linarin suppresses glioma through inhibition of NF- $\mathrm{kB} / \mathrm{p} 65$ and upregulating $\mathrm{p} 53$ expression in vitro and in vivo. Biomed Pharmacother., 2017; 95: 363-374.

24. Kang LJ, Choi YJ, Lee SG, Stimulation of TRAF6/ TAK1 degradation and inhibition of JNK/AP-1 signalling by ginsenoside $\mathrm{Rg} 3$ attenuates hepatitis $\mathrm{B}$ virus replication. Int J Biochem Cell Biol., 2013; 45(11): 2612-2621.

25. Lee IS, Uh I, Kim KS, Kim KH, Park J, Kim Y, Jung JH, Jung HJ, Jang HJ, Anti-Inflammatory Effects of ginsenoside Rg3 via $\mathrm{NF}-\kappa \mathrm{B}$ pathway in A549 cells and human asthmatic lung tissue. J Immunol Res., 2016; 2016: 1-11.

26. Bhargava S, Visvanathan A, Patil V, Kumar A, Kesari S, Das S, Hegde AS, Arivazhagan A, Santosh V, Somasundaram K, IGF2 mRNA binding protein 3 (IMP3) promotes glioma cell migration by enhancing the translation of RELA/p65. Oncotarget, 2017; 8(25): 40469-40485.

27. Du Z, Whitt MA, Baumann J, Garner JM, Morton CL, Davidoff AM, Pfeffer LM, Inhibition of type I interferon-mediated antiviral action in human glioma cells by the IKK inhibitors BMS-345541 and TPCA1. J Interferon Cytokine Res., 2012; 32(8): 368-377. 